\title{
Ermeneutica della rappresentazione: la preminenza del disegno nel confronto pluridisciplinare
}

\author{
Gerardo Maria Cennamo
}

Abstract

Questo contributo è parte di un ampio ambito di studio, già anticipato in altre occasioni di confronto scientifico, riguardante il disegno nel suo essenziale ruolo di sintesi e connessione delle molteplici variabili agenti nell'elaborazione dei processi percettivi. L'argomento offre molteplici chiavi di lettura e codici di declinazione, diramandosi in interessi disciplinari specialistici e molto diversi tra loro: volendo delimitarlo a una dimensione prossima alle scienze della rappresentazione, sembra interessante esplorare l'interazione tra i molteplici fattori componenti la dimensione simbolico-emotiva nell'ambito del complesso meccanismo di definizione della realtà esteriore, ovvero di quell'immagine che costruiamo a valle del processo cognitivo che la elabora e la definisce. In questa ampia tematica affiora una consapevolezza: il disegno, la forma elaborata per mente umana, dà spunto sia all'inizio che alla conclusione di questo intenso percorso.

Parole chiave

percezione, disegno, visione esteriore-interiore, trasposizione.
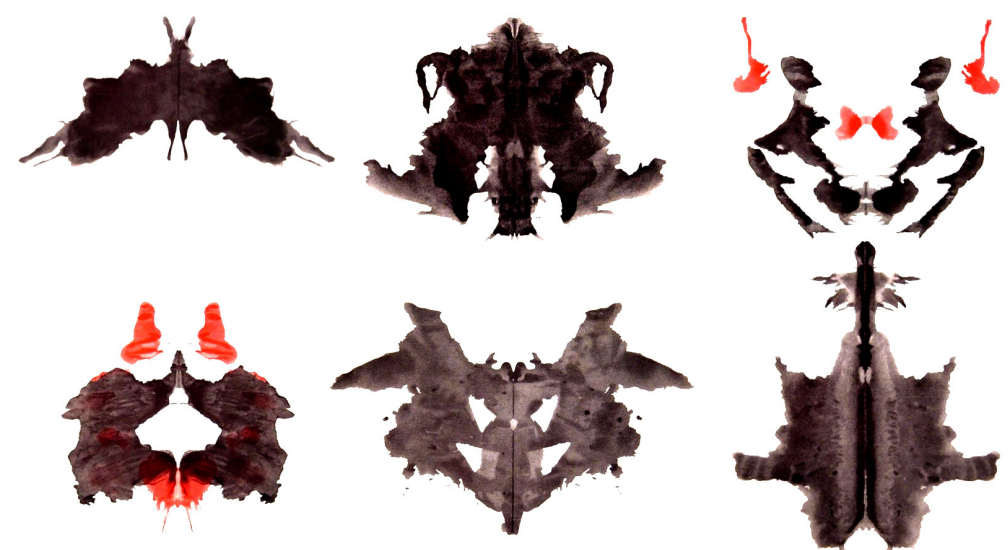


\section{Introduzione}

Il tema del convegno apre a riflessioni ampie e ci induce a proseguire nella linea di ricerca già anticipata nel 2019, con il contributo dal titolo Rappresentazione e coscienza: i poteri del disegno nella elaborazione degli stati cognitivi.

Se partiamo dal presupposto di potere 'oltrepassare il semplice pensiero razionale', affascinante sfida introdotta nell'apertura dei lavori dello scorso anno, possiamo dunque esplorare la possibilità di dare 'forma e misura' ad alcuni dei tanti meccanismi che governano le dinamiche della sfera percettiva all'interno della complessa struttura cognitiva umana. Attraverso il fil rouge del disegno.

Il disegno assume il potere di contenere e sintetizzare qualunque forma di emozione attivando, nell'osservatore, la pluralità delle aree cognitive, agendo sia sulla sfera emotiva che su quella razionale. Mentre altre forme di espressione stimolano ambiti cognitivi specifici, come musica, teatro o pittura che agiscono su quello emotivo maggiormente che su quello razionale, il disegno crea all'unisono connessioni sia con l'uno che con l'altro. Un'immagine ha la capacità di suscitare felicità, stupore, interesse intellettuale, o, semplicemente, emozioni diametralmente opposte [I].

La potenza espressiva del disegno è in proporzione diretta alla sua semplicità. Nei suoi studi di fisiologia della percezione Berthoz elabora la teoria della semplessità [2], neologismo descrivente una 'semplicità complicata': "il disegno è di per sé uno strumento mentale semplesso" [Berthoz 201 I, p. I43].

D'altronde, come riferiva lo stesso Matisse riguardo alla pittura in un'intervista del 1952, questa qualità del disegno ne definisce la capacità di sintesi e non lede, anzi ne amplifica, la pienezza di fondamento linguistico: "Ma la massima semplicità coincide con la massima pienezza. II mezzo più semplice libera al massimo della chiarezza lo sguardo per la visione. E alla lunga, solo il mezzo più semplice è convincente" [Massironi 1982, p. 42].

II portato semantico del disegno può essere ritenuto onnicomprensivo. Ha concorso ai fondamenti della psicodiagnostica con il noto Test di Rorschach (cover) utilizzato per indagare la personalità dei pazienti attraverso la visione di immagini grafiche [Morgenthaler 198I]; continua a rinnovarsi nell'era digitale con il lavoro della giovane artista Olivia de Recat [3] che è riuscita a rappresentare, con l'estrema semplicità e la dirompente intensità di poche linee, alcune tra le più importanti interazioni affettive della vita umana (fig. I).

Fig. I. Disegno di Olivia de Recat: Closeness Lines OverTime, (rielaborazione di contenuti disponibili in rete). Da sinistra verso destra: migliori amici di infanzia; amicizia interessata; migliori amici di università; un incontro in un momento sbagliato e poi in quello sbaglta fro giusto, fratellanza, amante occasionale, genitori; terapista; primo amore cane.

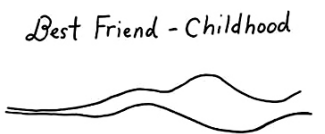

Dest Friend-College

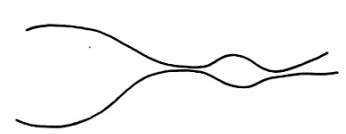

Sibling

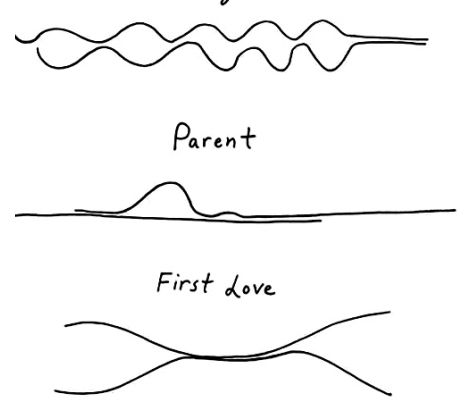

Friend With Benefits

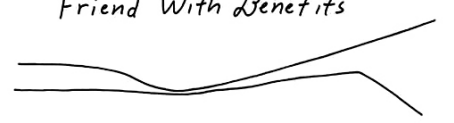

Someone You Meet at the Wrong Time, Then Re-Meet at the Right One

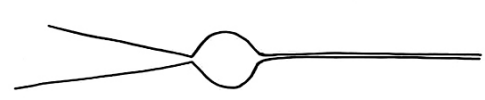

One night Stand

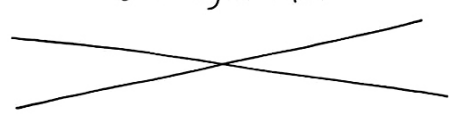

Therapist

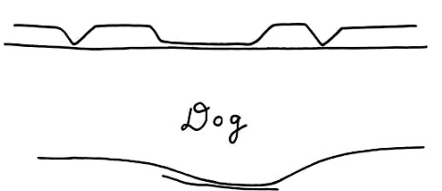




\section{Connettere}

Il tema delle connessioni, ancora presente negli argomenti di questo convegno, non può trascendere da una preliminare analisi su quel che riguarda la percezione della realtà esteriore e, per essa, se raffigurazione reale o artificiale. L'immagine, ovvero la sua costruzione, prende forma dall'elaborazione di una serie di sollecitazioni sensoriali ed emozionali che possono travalicare l'ambito strettamente visivo, iconografico o figurato.

In questa complessa interazione di connessioni partecipano molteplici fattori immateriali, come il tempo, ma anche il suono rappresenta un fondamentale parametro nella costruzione di un'immagine; essi intervengono nella fase di osmosi sensoriale e, quindi, nel momento in cui la nostra struttura percettiva si attiva verso la discretizzazione di ciò che proviene dall'ambiente esterno, costituendo la base informativa per la costruzione dell'immagine finale.

Ma quale è, in definitiva, l'immagine considerabile come reale?

II complesso di informazioni proveniente dall'esterno e, quindi, quello ipotizzabile reale, appare come l'astrazione interiore che ognuno di noi elabora in maniera automatica o, più correttamente, in misura indipendente dalla propria coscienza razionale. Per quest'ultima considerazione, oltre le molte tesi sviluppate dalla psicologia cognitiva e dalle neuroscienze cui, per brevità, rimandiamo, si ricordano le ricerche sperimentali di Yarbus nella metà del secolo scorso [Yarbus 1967]; obiettivo di quegli studi era dimostrare che la visione è un processo attivo, articolato attraverso una sequenzialità di movimenti oculari che selezionano le parti dell'immagine meritevoli di maggiore intensità di focalizzazione (fig. 2): "Il lavoro di Yarbus [...] ha dimostrato che la registrazione dei movimenti oculari delle persone varia drasticamente con le finalità $[. .$.$] non vi è dubbio che i modelli di movimento degli occhi$ sono influenzati da compiti di alto livello" [Lipps 2004, p. I I5].

II pensiero di Yarbus trova assonanze fondate nella cibernetica [4] e in particolare nelle teorie sul concetto di 'mappa mentale' che la descrivono come una cornice identificativa, il pattern figurato entro cui ricomporre l'immagine percepita, razionalizzandone l'informazione
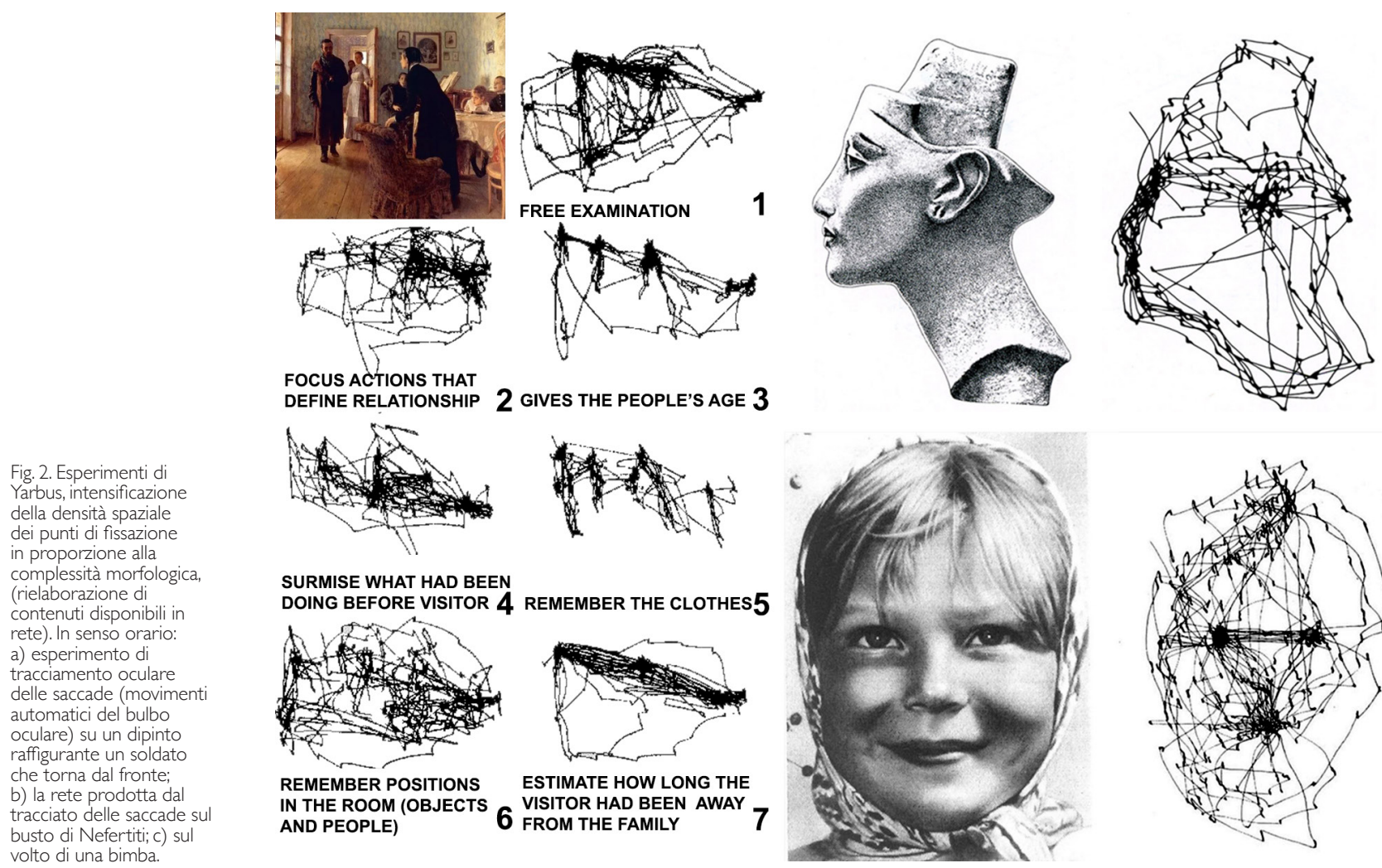

SURMISE WHAT HAD BEEN

DOING BEFORE VISITOR 4 REMEMBER THE CLOTHES 5
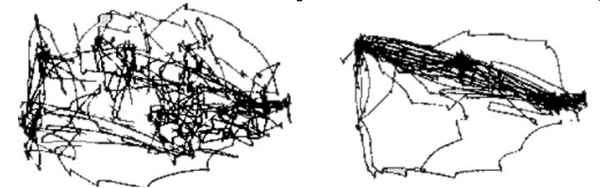

REMEMBER POSITIONS IN THE ROOM (OBJECTS
AND PEOPLE)

ESTIMATE HOW LONG THE

6 VISITOR HAD BEEN
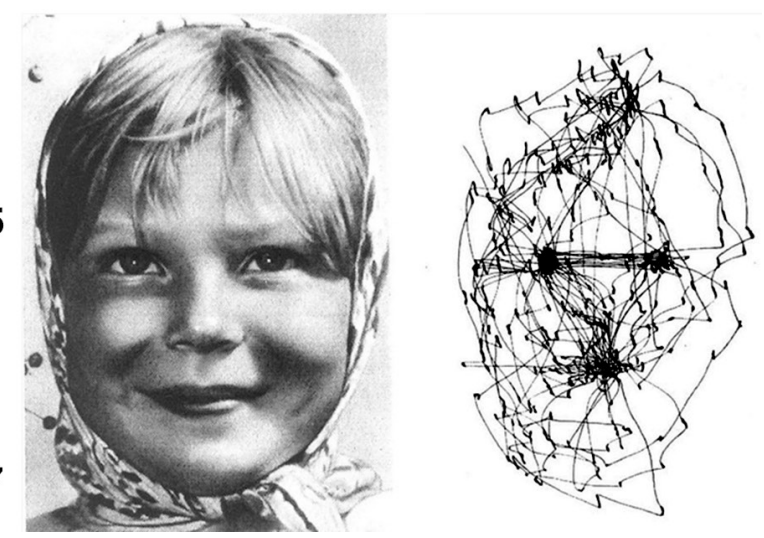
e controllandone il contenuto [Gombrich, Hochberg, Black 1972]. "Il disorientamento che può produrre un'opera d'arte... deriva dall'evocazione di contenuti molteplici e/o reconditi [...] la creazione di una mappa mentale del quadro seguirà livelli gerarchici di interpretazione visuale per poi ricomporsi in un pattern complessivo che rappresenterà l'esperienza soggettiva del quadro" [Forte 2004, p. 430].

Pur tuttavia va tenuto in conto che l'assenza di osservazione visiva non determina, di per sé, l'annullamento della capacità di elaborazione cognitiva conseguente alla vista di un'immagine. Così come il meccanismo della visione oculare si basa su un ribaltamento - codificato nella mente umana - del dato reale rilevato dall'esterno, così l'insieme delle informazioni provenienti dal mondo esteriore, percepite attraverso qualsiasi forma sensoriale e anche in mancanza della vista, definisce e ricostruisce un'immagine interiore; l'immagine disegnata, sia se riprodotta in forma esteriore che interiore, resta quindi sempre lo strumento principale di confronto per la costruzione della realtà.

II riferimento non è soltanto alla percezione aptica il cui sistema di captazione, secondo alcuni studi [Klatzky 1985], andrebbe a confinare in parte lo spazio elaborativo mentale, in quanto capace di estrarre informazioni direttamente attraverso i recettori epidermici; questa tesi motiverebbe anche la ridotta capacità di percepire opere pittoriche attraverso il solo sistema aptico, se non integrato in un sistema sensoriale più ampio che vada a innescare processi elaborativi mentali più articolati [Kennedy 1993]. Gli studi sulle neuroscienze, infatti, non hanno ancora codificato la mappatura delle complesse dinamiche elaborative della mente durante, ad esempio, la contemplazione di un'opera d'arte [Horgan 2003].
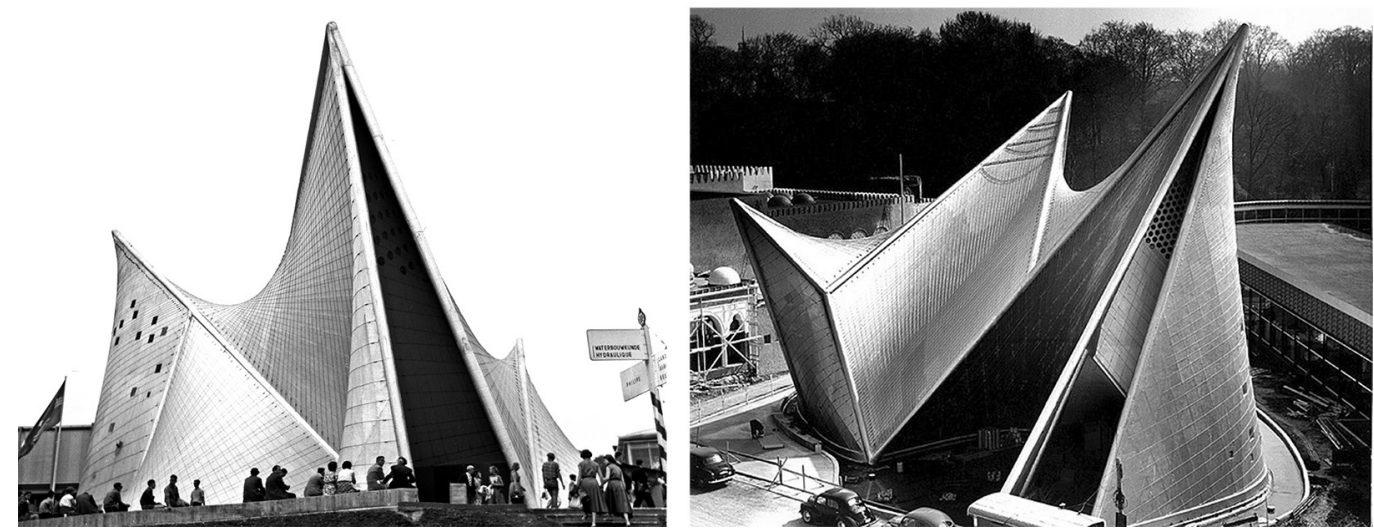

\section{Suono, forma e rappresentazione}

Nell'ermeneutica delle scienze della rappresentazione, il suono rappresenta una componente fondamentale per l'analisi e la percezione della realtà esteriore. Volendo proporre un distinguo attraverso un parossismo figurato, possiamo riferirci a due ambiti conclusi, quello visivo e quello acustico: il nostro sistema sensoriale modula la percezione dello spazio attraverso l'azione combinata e disgiunta dei due sensi [Pasotti 1995].

Spazio e suono vivono un dualismo dinamico: il suono si propaga all'interno dello spazio, lo spazio lo contiene e ne modula la propagazione.

Questa capacità viene esaltata in alcuni organismi architettonici, dove il suono evolve a una dimensione simbolico-rappresentativa attraverso la codifica di elementi sintattici riconoscibili. Su questo argomento e in particolare sul trinomio 'suono, forma e rappresentazione', offrono spunti di approfondimento gli studi del compositore Enrico Cocco: "I binomi avanti-indietro, sinistro-destro, sopra-sotto sono orientamenti spaziali ma nel contempo categorie che assumono anche valenze rappresentative articolabili linguisticamente come coppie di opposti, al pari delle altezze o delle durate dei suoni quali ad esempio alto-bas- 
Fig. 4. Rapporto tra luce e percezione, studi di Rosario Marrocco. Prima Rosario Marocco. Prima sequenza. Roma Stazione ponte Pietro Nenni: ponte Pietro Nenni; terza: Roma Lungotevere [Cennamo, Marrocco 2019]. so, breve-lungo, forte-piano" [Cocco 2009]. Analogamente alla percezione oculare, quella uditiva consente di elaborare una risposta in forma di costruzione di immagini. Si rinvia, ad esempio, all'architettura catacombale, che si modella sulla frequenza del parlato sottovoce e dei suoni deboli, alle costruzioni romaniche che esaltano i suoni gravi, alle cattedrali gotiche strettamente relazionate ai suoni acuti, agli impianti barocchi che privilegiano i suoni complessi, alle costruzioni rinascimentali e neoclassiche che evidenziano i suoni forti [Trematerra 2013; Trematerra 2014].

L'accostamento tra suono e disegno dell'architettura offre molti esempi autorevoli, come le sperimentazioni progettuali di Le Corbusier e del ingegnere-musicologo Xenakis per l'Esposizione Universale di Bruxelles del I958: il Padiglione Philips (fig. 3) si articolava in una complessa struttura architettonica disegnata da paraboloidi-iperbolici, all'interno della quale la diffusione del suono seguiva percorsi sonori capaci di assecondare le superfici complesse dell'architettura. In questo esempio magistrale la sovrapposizione tra disegno e onde sonore è esaltata e palese, il suono era contenuto e al tempo stesso conteneva l'architettura [Capanna 2000].

Lo spazio architettonico e urbano vive una continua e indissolubile relazione con il suono e, attraverso esso, ne muta la percezione. Al pari del variare della luce [Cennamo, Marrocco 2019, pp. |5.|-|5.|4], ad esempio, il suono di una città varia sensibilmente in determinati tempi o condizioni, influenzandone fortemente l'immagine percepita (fig. 4).

Si parla addirittura di "paesaggio sonoro" negli studi del compositore ambientalista Raymond Murray Schafer, nei quali vengono identificate e catalogate alcune qualità acustico-spaziali applicabili alla dimensione topografica e architettonica.

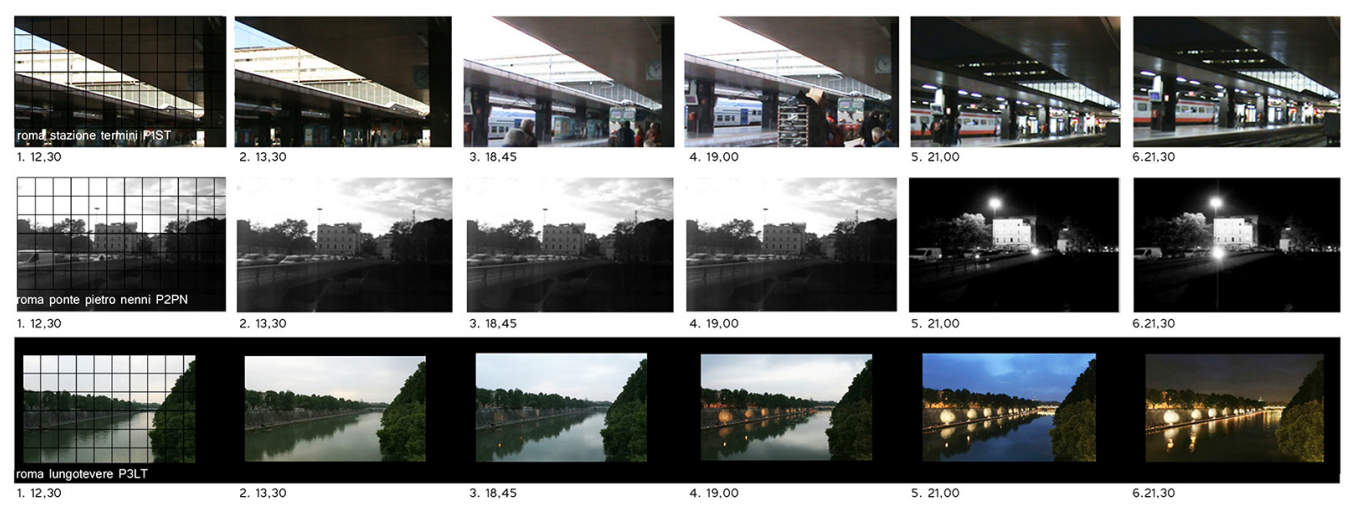

\section{Luogo reale e percepito}

La connessione di immagini diverse (reali, artificiali o elaborate mentalmente) definisce, anche, l'idea di 'luogo', secondo un'accezione analoga a quella della psicologia ambientale che individua nel luogo una dimensione soggettiva, fortemente legata alla percezione di chi a esso si rapporta: "la rappresentazione, la proiezione visiva, o la corrispondente proiezione mentale e sentimentale del territorio" [Turri 2003, p. 23].

Il luogo è quindi il risultato dell'intensa opera di costruzione derivante dall'azione del connettere, il prodotto del complesso sistema matriciale i cui elementi si formano sia per stimoli esogeni che per fattori endogeni (fig. 5).

Questo concetto si specifica in alcuni studi afferenti alla disciplina della geografia della percezione, rivolti alla 'dimensione soggettiva del mondo'. Le ricerche in questo ambito evolvono, dandone fondamento scientifico, da una corrente di pensiero degli anni '60 del secolo scorso che, negando l'esistenza di un mondo oggettivo, sosteneva l'esistenza di diversi 'ambienti di comportamento' a seconda degli individui e dei gruppi sociali considerati [Bianchi 2003]. La capacità di costruire l'immagine e la narrazione del proprio ambiente attraverso l'imma- 
ginario collettivo è stata indagata da alcuni autori, come il geografo Frèmond, relazionandola al concetto di radicamento, collegato alla capacità dell'uomo di plasmare il proprio ambiente [Fremond 2007]. Alcuni luoghi restituiscono in maniera più evidente un risultato che deve intendersi come la sommatoria di infinite prove, una lettura che proviene da molteplici e diversi punti di vista. Un'immagine che è il risultato dell'immagine costruita da osservatori diversi, con diverse finalità, diversi stati d'animo, diversi occhi-menti-coscienze. Interviene, nella sintesi di queste complesse relazioni, il bagaglio mnemonico che ognuno di noi reca in sé, costituendo un ulteriore fattore coadiuvante alla definizione della realtà esterna. La memoria, singola o collettiva, in uno al tempo col quale essa si relaziona e dal quale essa è governata, rappresenta uno dei fattori da interpolare nella complessa matrice di costruzione della realtà figurata.

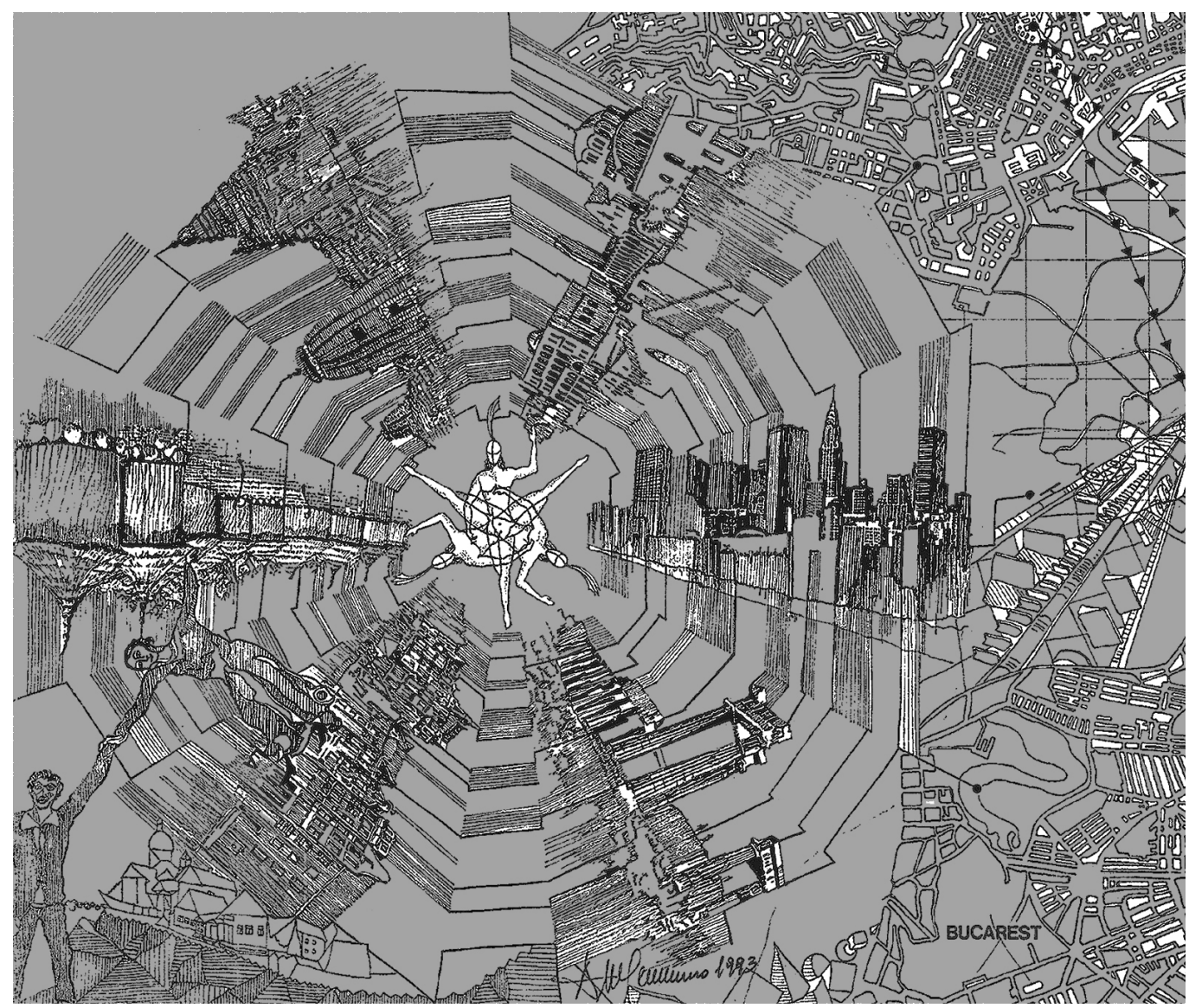

Nel rapporto biunivoco tra immagine reale e interiore, anche la memoria assume un significato dirimente nell'ambito della dialettica tra realtà esteriore e figurata.

Il luogo incarna, nel comune sentimento, un significato di immutevolezza, di solidità atavica. L'immagine che serbiamo del luogo ove siamo nati resta la fotografia di un dato momento, spesso distante nel tempo e ancor più per mutati stati d'animo. I luoghi si fissano nel nostro ricordo visivo come una immagine statica che ci riporta, al solo rievocarla, in uno stato diverso da quello contingente, a persone o vite diverse. II disegno dei nostri luoghi costruisce una matrice sensoriale nella quale la sollecitazione di un singolo elemento, ricordo, visione, odore, sapore, innesca l'attivazione di una lunga serie di connessioni. Il racconto di un luogo non può che essere affidato al suo disegno. 


\section{Conclusioni}

La conclusione di questo breve contributo non può che ricollegarsi alle condizioni in premessa e, quindi, alle considerazioni sulla vastità del portato espressivo del disegno che abbraccia, contiene e definisce qualunque forma del processo elaborativo mentale, sia essa appartenente alla sfera propriamente emozionale che a quella razionale. Questa capacità di decifrare ogni complessità attraverso regole sintattiche semplici ed efficaci stabilisce una precisa dicotomia tra l'onnicomprensività del portato semantico e la semplicità del linguaggio espressivo che non trova pari in nessun'altra forma linguistica: "Nel disegno si cessa di girare intorno all'immagine: ci si ferma in un punto. E si contempla" [Pierantoni 1999, p. 128]. La circolarità fra mente, realtà e percezione, così come può essere 'racchiusa' in un disegno, trova una possibile soluzione nella metafora rappresentata da Escher con La Galleria di Stampe (fig. 6), titolo originario Prentententoonstelling, ove l'osservatore si smarrisce in una successione di ribaltamenti della prospettiva di visuale che inducono nella stupefacente illusione percettiva di sentirsi dentro e fuori dal quadro: "la città è oggetto del quadro e soggetto della scena, quindi è 'dentro', ma è anche 'fuori'” [Forte 2004, p. 432]. Tutto un mondo racchiuso in un disegno.

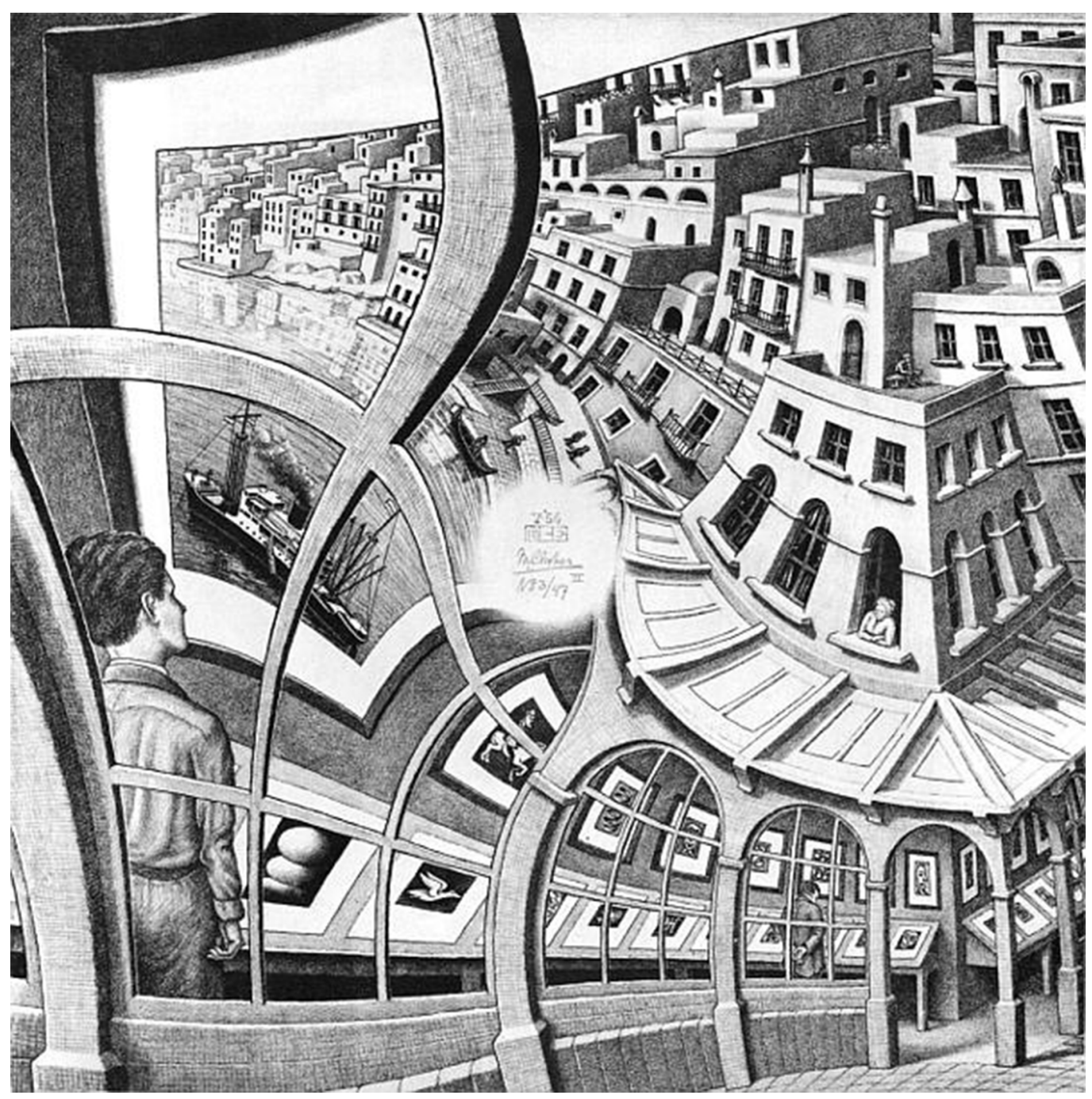




\section{Note}

[I] L'argomento amplia quello presentato al convegno 2019 [cfr. Cennamo 2019, pp. I63-I70].

[2] La teoria della semplessità postula la capacità del subconscio cognitivo di anticipare le azioni razionali, come spiega l'autore alla pagina 173:" "la percezione è sempre simulazione di un'azione nel mondo, la percezione cosciente è sempre un'anticipazione di un qualche evento che si produrrà nel mondo, a prescindere dal fatto che l'evento sia prodotto dal soggetto percepente oppure no". Questa capacità evolve attraverso un'intensa attività di connessioni che non configurano un processo semplice, bensì molto articolato, come chiarisce l'autore nelle premesse alla pagina 5: "semplessità non è semplificare [...] Richiede di inibire, selezionare, collegare e immaginare".

[3] Cfr. https://www.oliviaderecat.com/shop/closeness-lines-print (consultato il 20 marzo 202I).

[4] Cfr. <https://www.treccani.it/enciclopedia/cibernetica> (consultato il 20 marzo 202I), definizione in Treccani on line: Cibernetica, disciplina che si occupa dello studio unitario dei processi riguardanti “la comunicazione e il controllo nell'animale e nella macchina". Può anche essere definita come lo studio generale di sistemi complessi altamente organizzati, indipendentemente dalla loro particolare natura.

[5] Cfr. Murray Schafer R., World Soundscape Project, 1960-1970

\section{Riferimenti bibliografici}

Berthoz A. (20I I). La semplessità. Torino: Codice Edizioni.

Bianchi E. ( 1 987). Comportamento e percezione dello spazio ambientale. Dalla Behavioral Revolution al Paradigma umanistico. In G. Corna Pellegrini. (a cura di). Aspetti e problemi della geografia, vol. I. Milano: Marzorati Editore.

Capanna A. (2000). Le Corbusier, Padiglione Philips, Bruxelles. Universale di Architettura. Torino:Testo \& Immagine.

Forte M. (2004). Realtà virtuale, beni culturali e cibernetica: un approccio ecosistemico. In Archeologia e Calcolatori I5, pp. 423-448.

Frémond A. (2007). Vi piace la geografia?. Roma: Carocci.

Gombrich E., Hochberg J., Black M. (1972). Arte, percezione e realtà. Torino: Einaudi.

Horgan J. (2003). La mente inviolata. Una sfida per la psicologia e le neuroscienze. Milano: Raffaello Cortina Editore.

latzky R., Lederman S., Metzger V. (1985). Identifying objects by touch: An "expert system". In Perception \& Psychophysics, 37, pp. 299-302.

Kennedy J. (1993). Drawing and the blind: Pictures to touch. New Haven:Yale University Press.

Lipps M., Pelz J. (2004). Yarbus revisited: task-dependent oculomotor behavior. In Journal of Vision, vol. 4.

Massironi M. (1982). Vedere con il disegno. Padova: F. Muzzio.

MorgenthalerW. (a cura di) (198I). Psicodiagnostica Hermann Rorschach. Roma: Edizioni Kappa.

Pasotti S. (1995). Rappresentazione Linguaggi Ermeneutica. Lanciano: Editrice Itinerari.

Pierantoni P. ( 1999). Forma fluens. Il movimento e la sua rappresentazione nella scienza, nell'arte e nella tecnica. Torino: Bollati Boringhieri.

Trematerra A., lannace G. (20/3). The acoustic of the Catacombs of "San Gennaro" in Naples. Proceedings of International Congress on Noise Control Engineering, Innsbruck.

Trematerra A., lannace G. (20|4). The Acoustic of caves. In Applied Acoustics, 86.

Turri E. (2003). Il paesaggio degli uomini: la natura, la cultura, la storia. Bologna: Zanichelli.

Yarbus L. (1967). Eye Movements and Vision. New York: Plenum Press.

Autore

Gerardo Maria Cennamo, Università Telematica Internazionale UNINETTUNO, g.cennamo@uninettunouniversity.net

Per citare questo capitolo: Cennamo Gerardo Maria (202I). Ermeneutica della rappresentazione: la preminenza del disegno nel confronto pluridisciplinare/Representation's hermeneutics: the supremacy of the drawing in the multidisciplinary comparison. In Arena A., Arena M., Mediati D. Raffa P. (a cura di). Connettere. Un disegno per annodare e tessere. Linguaggi Distanze Tecnologie. Atti del $42^{\circ}$ Convegno Internazionale dei Docenti delle Discipline della Rappresentazione/Connecting. Drawing for weaving relationship. Languages Distances Technologies. Proceedings of the $42^{\text {th }}$ International Conference of Representation Disciplines Teachers. Milano: FrancoAngeli Milano: FrancoAngeli, pp. 378-393. 


\title{
Representation's Hermeneutics: the Supremacy of the Drawing in the Multidisciplinary Comparison
}

\author{
Gerardo Maria Cennamo
}

Abstract

This paper is part of a broader research, already discussed in other past scientific conventions, concerning the drawing as the principal tool of synthesis and connection of the several variables that acting in the elaboration of perceptual processes. The argument offers multiple interpretations and some declination codes, branching off into some specialized and very different disciplinary interests: wanting to limit its intellectual dimension to the sciences of representation issues, it seems interesting to explore the interaction between the multiple factors making up our emotional dimension during the complex work of definition of external reality, or rather of that image that we build downstream of the cognitive process that elaborates and defines the same image. An awareness emerges in this broad theme: drawing, the image elaborated by the human mind, gives rise to both the beginning and the end of this intense journey.

Keywords

perception, drawing, outward-inward vision, transposition.
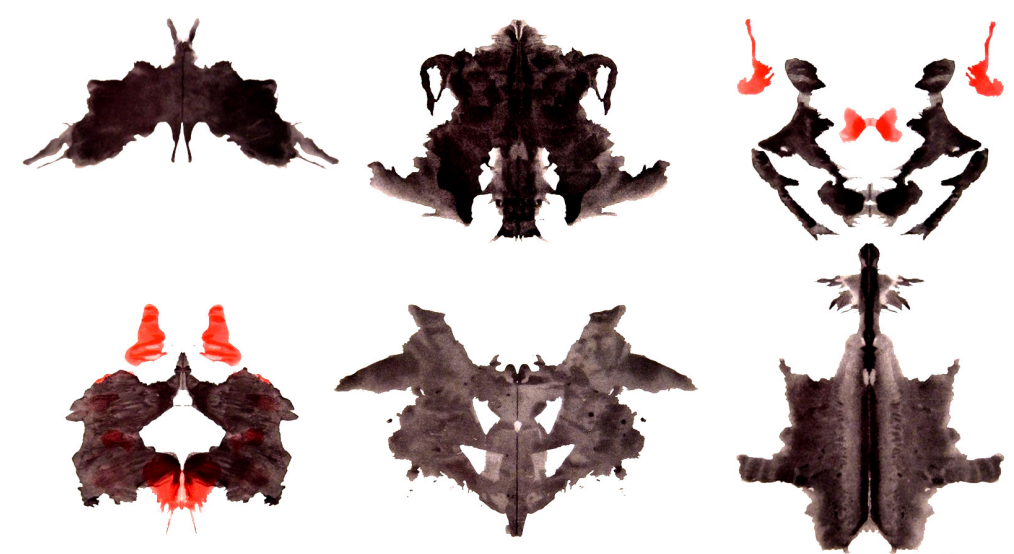

doi.org/ 0.3280/oa-693.21 


\section{Introduction}

The theme of the conference opens to broad reflections and invites us to continue the research already anticipated in the past 2019, with the contribution entitled Representation and conscience: the abilities of the drawing in the elaboration of cognitive states.

Starting from the assumption of being able to 'overstep the simple rational thought', a fascinating challenge introduced in the opening of last year's works, we can therefore investigate the possibility of giving a 'shape and measure' to some of the many mechanisms that govern the dynamics of the perceptual sphere. inside the complex human cognitive structure. Through the fil rouge of the drawing.

The drawing assumes the power to synthesize any form of emotion by activating, in the observer, the plurality of cognitive areas, acting on both the emotional and the rational sphere. While other forms of expression act on specific cognitive areas, such as music, theater or painting that act on the emotional one more than on the rational one, the drawing creates connections both with one and the other one. An image has the ability to arouse happiness, amazement, intellectual interest, or, simply, diametrically opposite emotions [I].

The expressive power of the design is in direct proportion to its simplicity. In his studies of the physiology of perception, Berthoz elaborates the theory of the semplessita [2], a neologism describing a 'complicated simplicity': "il disegno è di per sé uno strumento mentale semplesso" [Berthoz 201 I, p. I43].

On the other hand, as Matisse specified during an interview about the painting in the past 1952, this propiety of the drawing defines its synthesis capacity and does not diminish, rather it amplifies, the fullness of the linguistic foundation: "Ma la massima semplicità coincide con la massima pienezza. II mezzo più semplice libera al massimo della chiarezza lo sguardo per la visione. E alla lunga, solo il mezzo più semplice è convincente" [Massironi 1982, p. 42]. The semantic meaning of the drawing can be considered as all-encompassing. It contributed to the fundamentals of the psych diagnostics with the known Rorschach test (cover) used to investigate the personality of the patients through the vision of images [Morgenthaler 198 I]; it continues to renew itself in the digital age with the work of the young artist Olivia de Recat [3] who had the ability to represent, with the extreme simplicity and full intensity of a few graphic lines, some of the most important affective interactions of human life (fig. I).

Fig. I. Drawing by Olivia
de Recat, Closeness Lines Over Time, (processing of contents from Internet). Left to right: best friends/childhood friend with benefits; best friends/College: someone you meet at the wrong time, time re-meet at the right one; sibling; one night stand; parent; therapist; first love; dog.
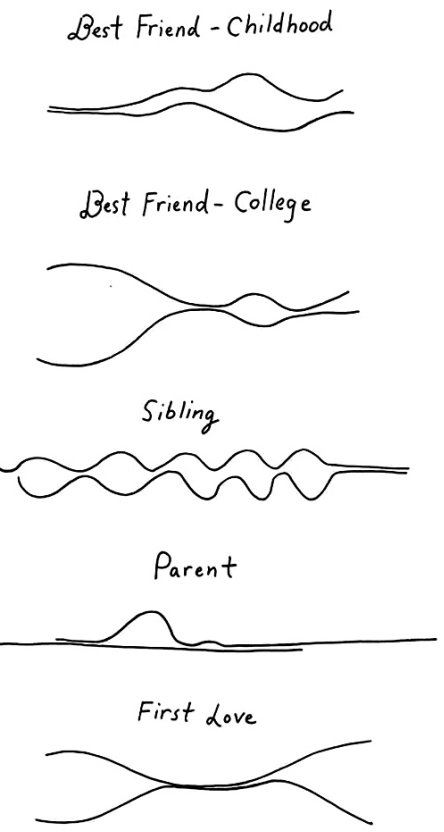

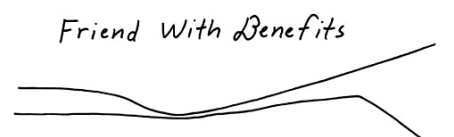

Someone You Meet at the Wrong Time, Then Re-Meet at the Right One

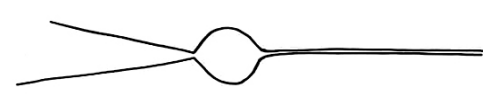

One night Stand

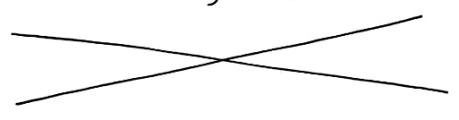

Therapist

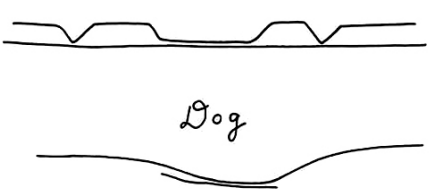




\section{Connecting}

The theme of the connections, still present in the topics of the next conference, cannot transcend from a preliminary analysis about the perception of external reality and, of itself, if it can be understood as a real or an artificial representation. The image, or its construction, develop its shape from the elaboration of a series of sensory and emotional stimuli that can go beyond the strictly visual, iconographic or figurative sphere.

Many immaterial factors participate in this complex interaction of connections, such as the time, but also the sound represents a fundamental parameter in the construction of a vision; this factor intervene in the phase of sensory osmosis and, therefore, in the same time activating our perceptual dynaimics in function of the discretization of the external solicitations, constituting the information base for the construction of the final image.

But what, ultimately, is the image that we can consider the real one?

The entirety of the information coming from the external environment and, therefore, that we can be hypothesized as the real one, appears as the internal abstraction that each of us processes automatically or, more correctly, independently of our rational conscience. In support of this last consideration, in addition to the many theses developed by cognitive psychology and neuroscience that, for the sake of brevity we cannot describe, we recall the experimental research of Yarbus of the middle of the last century [Yarbus 1967]; the main scope of those studies was to demonstrate that vision is an active process, articulated through a sequence of eye movements that select the parts of the image deserving of greater intensity of focus (fig. 2): "Il lavoro di Yarbus [...] ha dimostrato che la registrazione dei movimenti oculari delle persone varia drasticamente con le finalità $[\ldots]$ non vi è dubbio che i modelli di movimento degli occhi sono influenzati da compiti di alto livello" [Lipps 2004, p. II5].

Yarbus's thought finds assonances in the cybernetics [4] and in particular in the theories on the concept of 'mental map' which describe it as an identifying frame, the figurative pattern within which to recompose the perceived image, rationalizing the information and con-

Fig. 2. Yarbus tests on the spatial density of the fixation points demonstrating their density on the more morphologically complex details (processing of contents from Internet). Clockwise: a) eye tracking test of saccades (automatic movements of the eyeball) on a painting with a soldier returning from the front: b) the from the font, b) the the sacades on the bust of Nefertiti; c) on the face of a little girl.
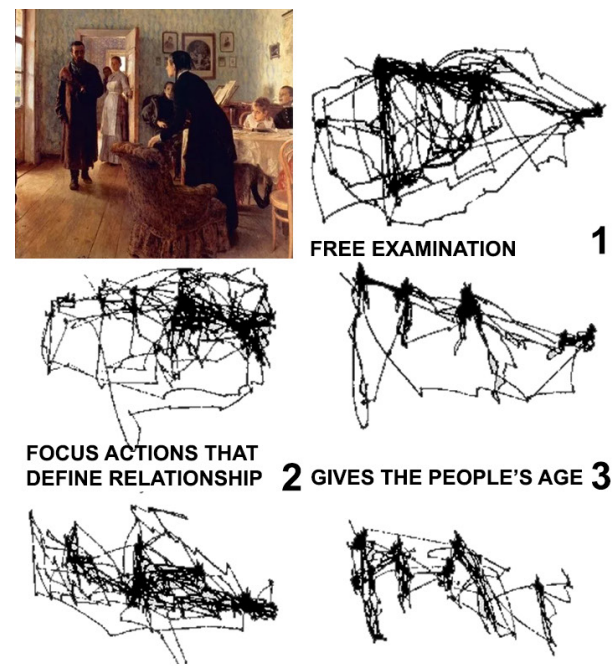

2 Gives the PEOPLE'S AGe 3
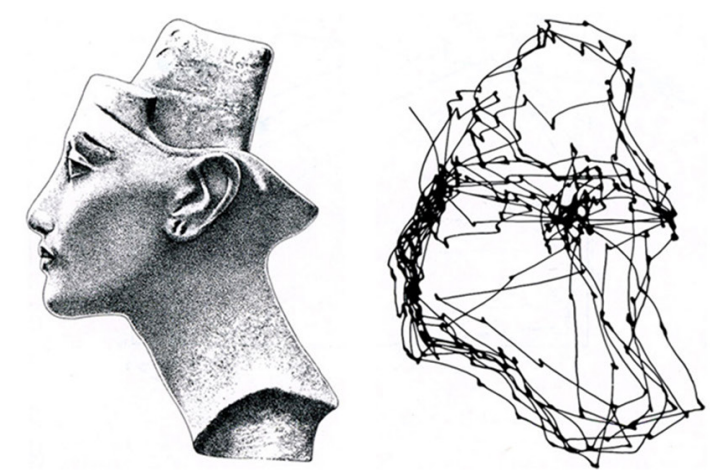

SURMISE WHAT HAD BEEN DOING BEFORE VISITOR 4 REMEMBER THE CLOTHES 5
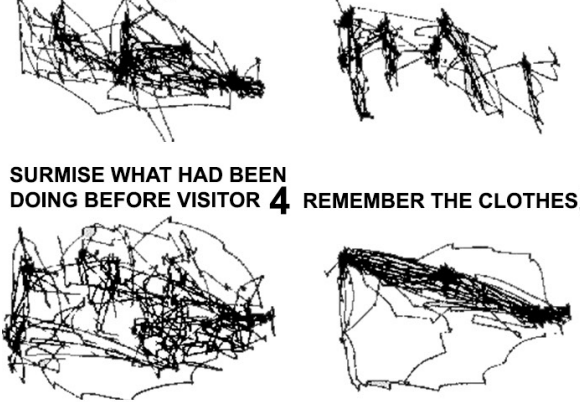

REMEMBER POSITIONS IN THE ROOM (OBJECTS AND PEOPLE)
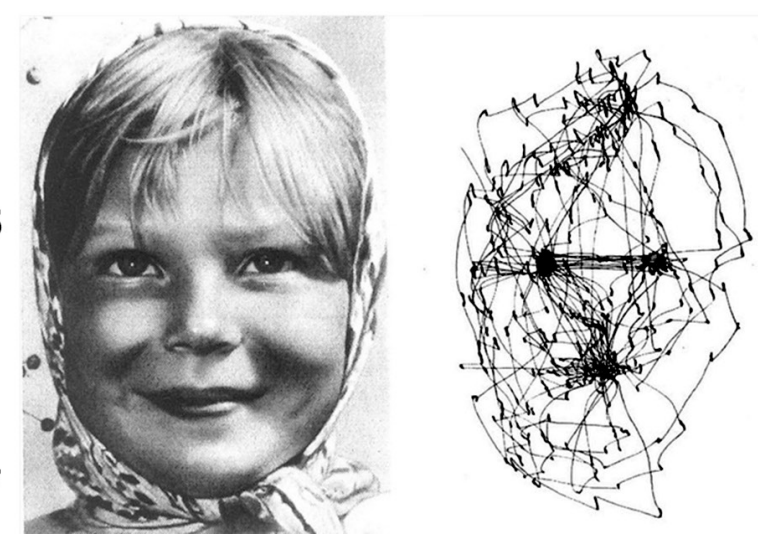
trolling its content [Gombrich, Hochberg, Black 1972]." "Il disorientamento che può produrre un'opera d'arte... deriva dall'evocazione di contenuti molteplici e/o reconditi [...] la creazione di una mappa mentale del quadro seguirà livelli gerarchici di interpretazione visuale per poi ricomporsi in un pattern complessivo che rappresenterà l'esperienza soggettiva del quadro" [Forte 2004, p. 430].

However, we must consider that the absence of a visual observation not directly determine the annulment of the cognitive processing capacity that follow to the sight of an image. Just as the mechanism of ocular vision is based on a reversal -encoded in the human mind- of the real data detected from the outside, so the set of information coming from the external world, perceived through any sensory form and even in the absence of the sight, defines and reconstructs an interior image; the drawn image, whether reproduced in external or internal form, remains the main comparison instrument using for the processing of reality vision.

The reference is not only to haptic perception whose capture system, according to some studies [Klatzky 1985], would partially reduce the mental processing space, since it is capable of extracting information directly through the epidermal receptors; this thesis would also motivate the reduced ability to perceive the painting through the haptic system alone, if not integrated into a wider sensory system that triggers more complex mental elaborative processes [Kennedy 1993]. In fact, studies about the neuroscience have not yet codified the mapping of the complex processing dynamics of the mind during, for example, the contemplation of a work of art [Horgan 2003].

Fig. 3. Philips Pavilion, Universal Exhibition in Brussels, 1958.
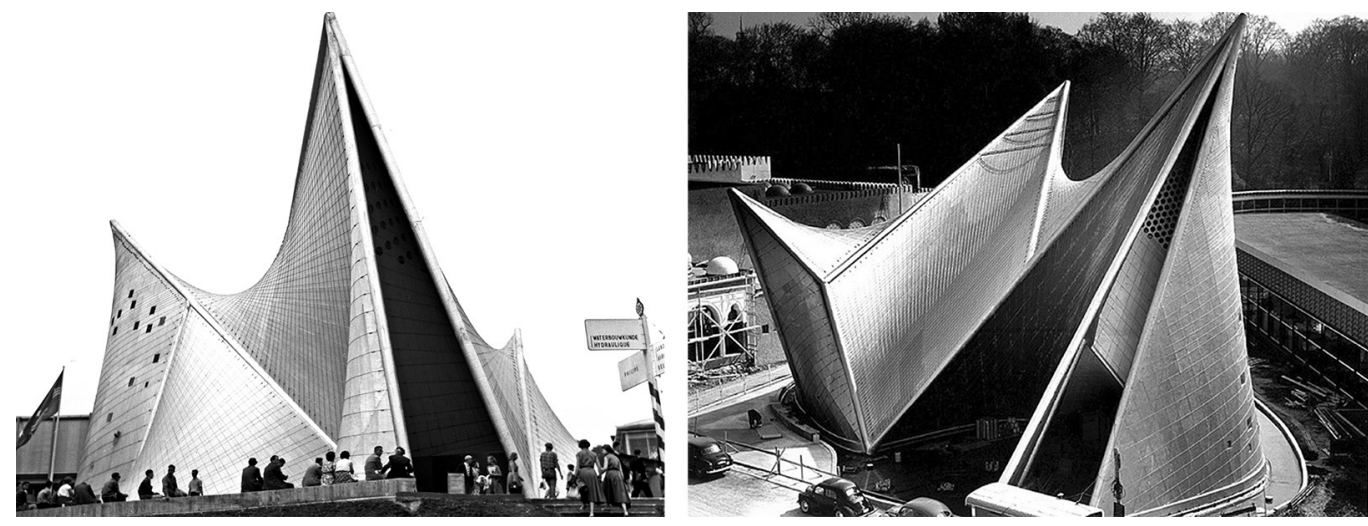

\section{Sound, shape and drawing}

In the hermeneutics of the representation issues, the sound represents a fundamental component for the analysis and perception of external environment. Wanting to propose a distinction through a figurative paroxysm, we can refer to two concluded areas, the visual one and the acoustic one: our sensory system modulates the perception of space through the combined and disjoint action of the two senses [Pasotti 1995].

The space and the sound experience a dynamic dualism: the sound propagates within the space, the space contains it and modulates its propagation.

This ability is enhanced in some architectural shapes, where sound evolves to a symbolic-representative dimension through the encoding of recognizable syntactic elements. On this topic, particularly about the trinomial 'sound, shape and representation', offer interesting insights the studies of the composer Enrico Cocco:"I binomi avanti-indietro, sinistro-destro, sopra-sotto sono orientamenti spaziali ma nel contempo categorie che assumono anche valenze rappresentative articolabili linguisticamente come coppie di opposti, al pari delle altezze o delle durate dei suoni quali ad esempio alto-basso, breve-lungo, forte-piano" [Cocco 2009] 
Fig. 4. The relationship between light and perception, study by Rosario Marrocco. First sequence: Roma, Termini Station second: Roma Pietro Nenni bridge: third: Roma Cennamo Marrocco Cennamo, Marrocco
In a similar way as the ocular perception, the auditory perception allows us to process a response in the form of an image construction. For example, we can refer to the catacomb architecture, which is modelled on the frequency of whispered speech and soft sounds, to the Romanesque buildings that enhance low sounds, to the Gothic cathedrals closely related to high-pitched sounds, to the baroque style that favor complex sounds or to Renaissance and neoclassical constructions that highlight loud sounds [Trematerra 20 I3; Trematerra 20 I4]. The comparison between sound and architecture offers many authoritative examples, such as the design that Le Corbusier with the engineer-musicologist Xenakis experimented for the Universal Exhibition in Brussels in 1958: the Philips Pavilion (fig. 3) was developed trought a complex architectural structure designed by hyperbolic-paraboloids, within which the diffusion of sound followed sound paths capable of supporting the complex architectural surfaces. In this masterful example the overlap between the architectural design and the sound waves is enhanced and evident, the sound was contained but at the same time it contained the architecture [Capanna 2000].

The urban and architectural enviroment is subordinate to a continuous and indissoluble relationship with the sound and, through it, its perception changes. Like the variation of the light [6], for example, the sound of a city varies significantly during different times or conditions, strongly influencing the perceived image (fig. 4).

The studies of the "environmental composer" Raymond Murray Schafer introduce the concept of 'sound landscape', identifying and cataloguing some acoustic-spatial qualities applicable to the topographical and architectural dimension [Cennamo, Marrocco 2019].

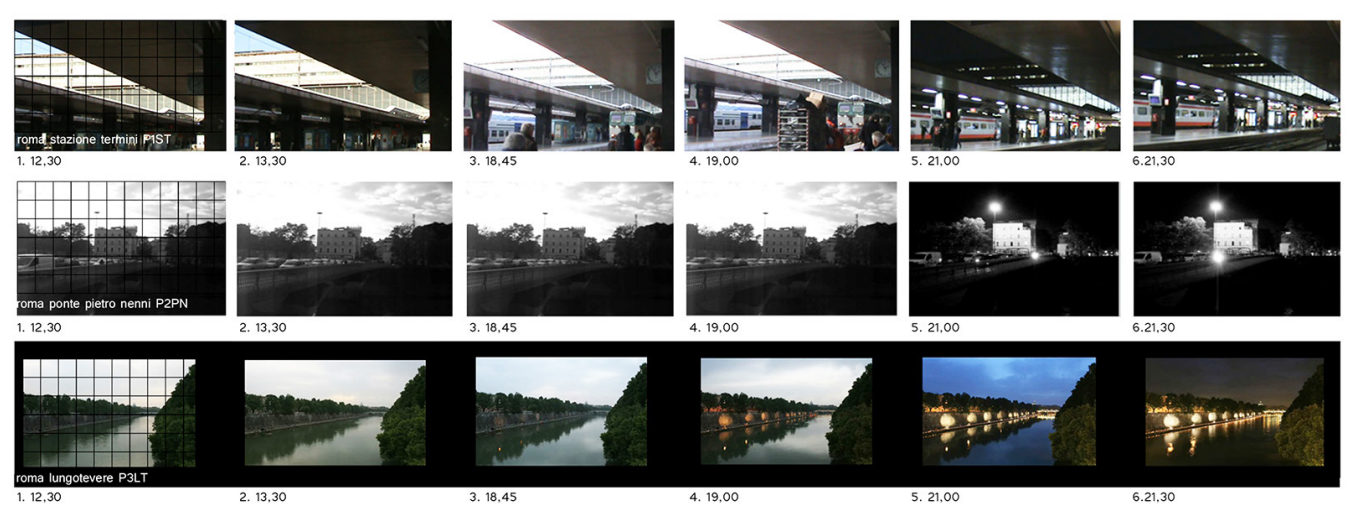

\section{Real place, perceived place}

The connection of some different images (real, artificial or mentally developed) also defines the idea of 'place', according to a meaning similar with the environmental psychology which identifies a subjective dimension in the place, strongly linked to the perception of those who relate to it: "la rappresentazione, la proiezione visiva, o la corrispondente proiezione mentale e sentimentale del territorio" [Turri 2003, p. 23].

The place is the result of an intense work resulting from the connecting action of the complex matrix system whose elements are formed both by exogenous stimuli and by endogenous factors (fig. 5).

This concept is specified in some studies relating to the discipline of geography of perception, focused in the 'subjective dimension of the world'. Research in this area evolved, giving it a scientific basis, from a current of thought of the 60 s of the last century which, denying the existence of an objective world, supported the existence of different 'behavioural environments' depending on the individuals and of the social groups considered [Bianchi 2003]. The ability to describe the vision and the narration of one's environment through the col- 
lective imagination, has been investigated by some authors, such as the geographer Frèmond that relating it to the concept of rootedness, connected to man's ability to shape his own environment [Fremond 2007]. Some places give a more evident result that must be understood as the sum of infinite tests, a reading that comes from multiple and different points of view. A final image that is the result of the image constructed by different observers, with different purposes, different moods, different eyes-minds-consciences. In the synthesis of these complex relationships, the mnemonic baggage that we carries within us come to light, constituting a further adjuvant factor in the definition of external reality. The memory, single or collective, in one at the time with which it relates and by which it is governed, represents one of the factors to be interpolated in the complex construction matrix of figurative reality. In the two-way relationship between real and interior image, the memory also takes on a decisive meaning in the context of the dialectic between exterior and figurative reality.

Fig. 5. Michele Cennamo, Multipolis, the connecting city, cover drawing, 1993; first prize in the International Competition for the 2 Ist century city.

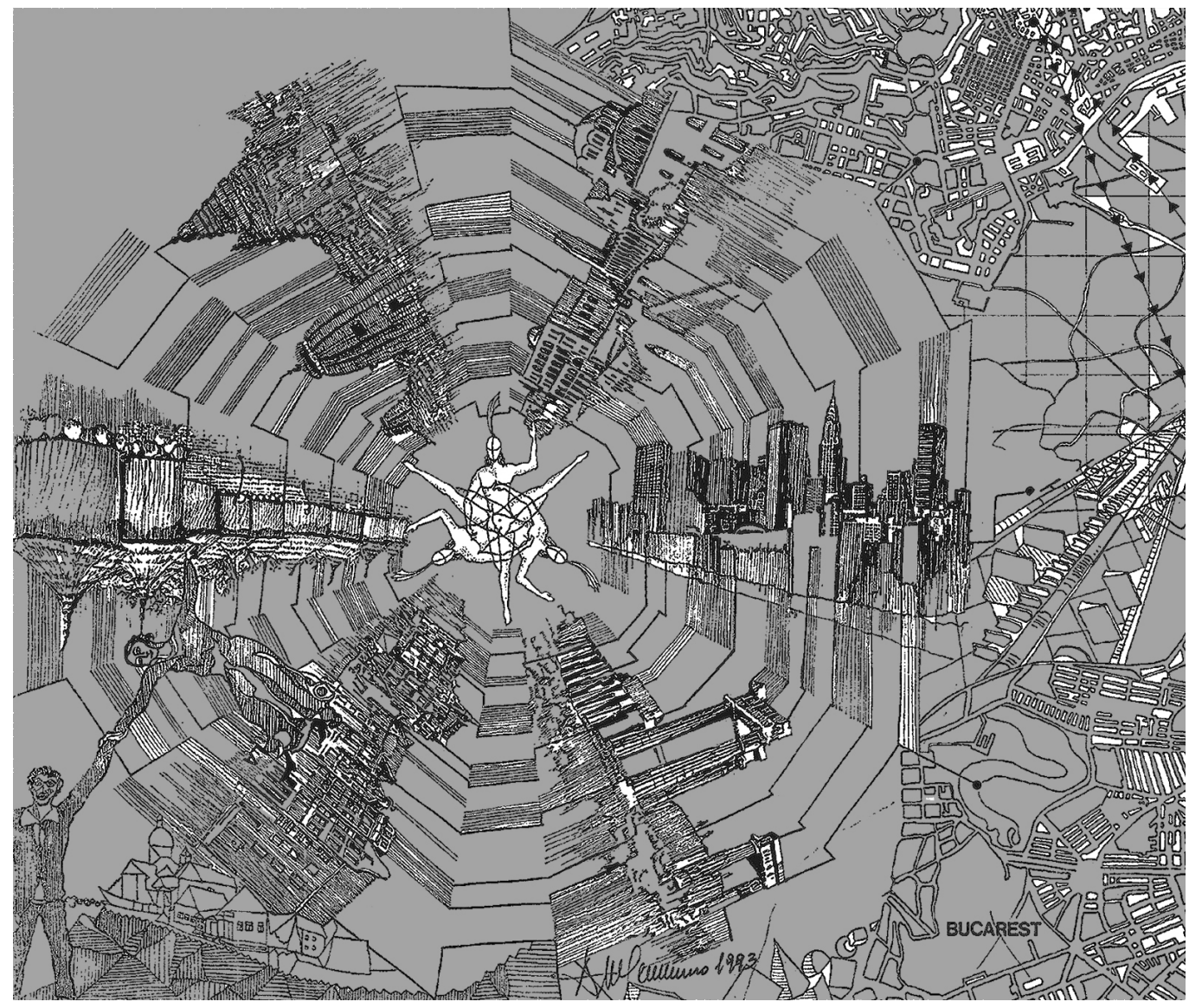

The place embodies, in the common feeling, a meaning of immutability, of atavistic solidity. The image we hold of the place where we were born remains the photograph of a given moment, often distant in time and even more so due to changed moods. The places are fixed in our visual memory as a static image that brings us back, only to recall it, in a different state from the contingent one, to different people or lives. The representation of our places builds a sensorial matrix in which the solicitation of a single element, memory, vision, smell, taste, triggers the activation of a long series of connections.

The story of a place can only be entrusted to its drawing. 


\section{Conclusions}

The conclusion of this short contribution can only be linked to the introduction's conditions and, therefore, to the considerations on the vastness of the expressive meaning of the drawing that enclose, contains and defines any expression of the mental elaborative process, both it belongs to the strictly emotional sphere than to the rational one. This ability to decipher every complexity through simple and effective syntactic rules establishes a precise dichotomy between the omnicomprehensiveness of the semantic dimension and the simplicity of the expressive language that is unmatched in any other linguistic form: "Nel disegno si cessa di girare intorno all'immagine: ci si ferma in un punto. E si contempla" [Pierantoni 1999, p. 128]. The circularity between mind, reality and perception, as it can be 'enclosed' in a drawing, finds a possible solution in the metaphor represented by Escher with he's drawing originally titled Prentententoonstelling (fig. 6), where the observer gets lost in a succession of reversals of the visual perspective that lead to the astonishing perceptual illusion of feeling inside and outside the painting: "la città è oggetto del quadro e soggetto della scena, quindi è 'dentro', ma è anche 'fuori"' [Forte 2004, p. 432].

A whole world enclosed in a drawing.

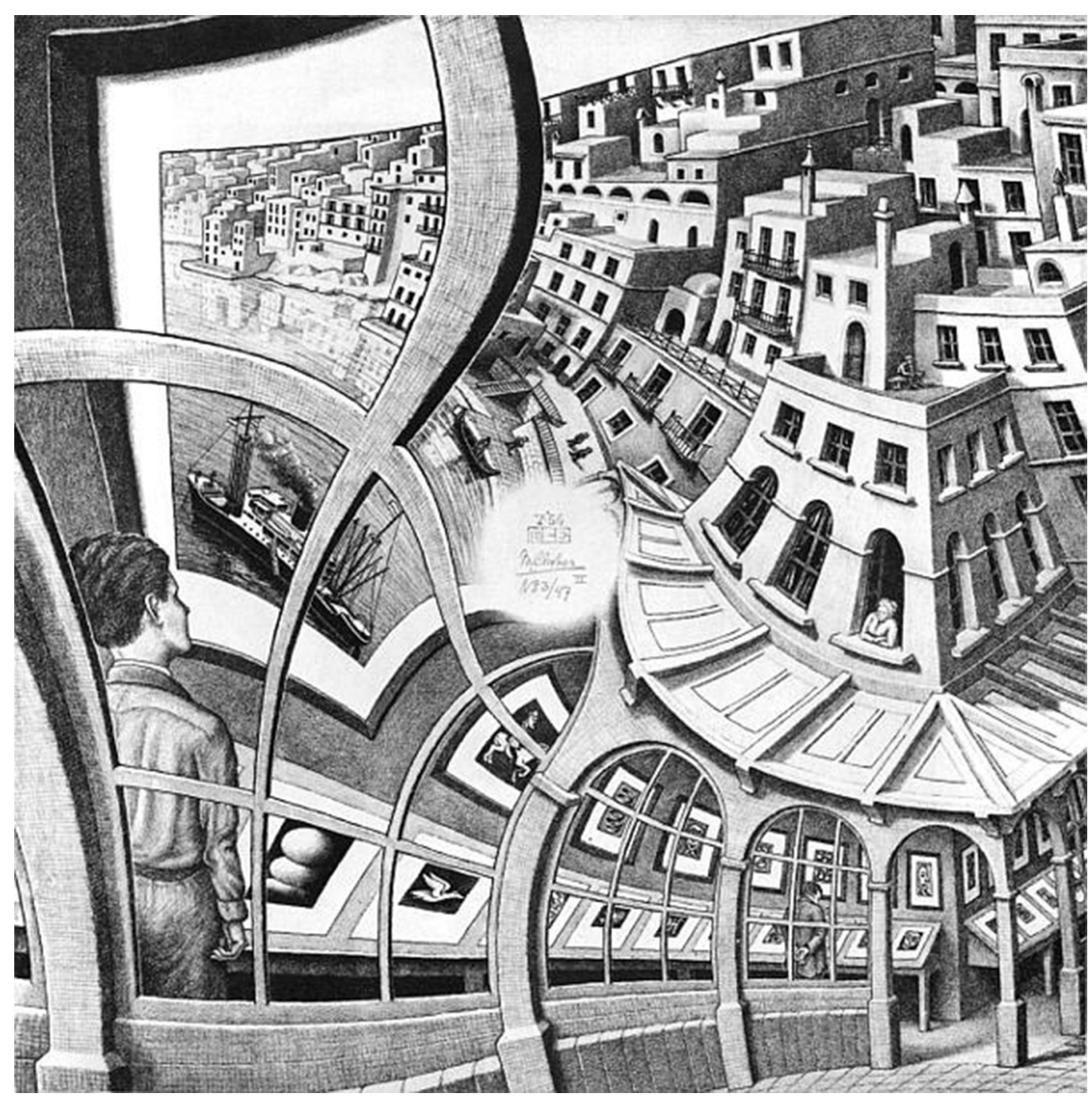




\section{Notes}

[I]The topic expands the research presented in the past conference [Cennamo 2019, pp. I63-170].

[2] The theory of semplessità postulates the ability of our subconscious to anticipate the rational actions, as the author write (p. 173): "perception is a simulation of an action in the world, conscious perception is always an anticipation of some event that will occur in the world, regardless of whether the event is produced by the perceiving subject or not". This ability develop through an intense connecting activity, that do not configure a simple process but a very complex one, as the author explains in the introduction of his essay (p. 5): "simplicity is not simplification [...] It requires inhibiting, selecting, connecting and imagining".

[3] <https://www.oliviaderecat.com/shop/closeness-lines-print> (accessed 202 I, March 20).

[4] <https://www.treccani.it/enciclopedia/cibernetica> (accessed 2021, march 20) by Treccani on line: "Cybernetics...a discipline that focus on the study of processes concerning the communication and control in animals and machines. It can also be defined as the general study of highly organized complex systems, regardless of their nature".

[5] Murray Schafer, The World Soundscape Project, 1960-1970.

\section{References}

Berthoz A. (20 I I). La semplessità. Torino: Codice Edizioni.

Bianchi E. ( 1 987). Comportamento e percezione dello spazio ambientale. Dalla Behavioral Revolution al Paradigma umanistico. In G. Corna Pellegrini. (a cura di). Aspetti e problemi della geografia, vol. I. Milano: Marzorati Editore.

Capanna A. (2000). Le Corbusier, Padiglione Philips, Bruxelles. Universale di Architettura. Torino:Testo \& Immagine.

Forte M. (2004). Realtà virtuale, beni culturali e cibernetica: un approccio ecosistemico. In Archeologia e Calcolatori I5, pp. 423-448.

Frémond A. (2007). Vi piace la geografia?. Roma: Carocci.

Gombrich E., Hochberg J., Black M. (1972). Arte, percezione e realtà. Torino: Einaudi.

Horgan J. (2003). La mente inviolata. Una sfida per la psicologia e le neuroscienze. Milano: Raffaello Cortina Editore.

latzky R., Lederman S., Metzger V. (1985). Identifying objects by touch: An "expert system". In Perception \& Psychophysics, 37, pp. 299-302.

Kennedy J. (1993). Drawing and the blind: Pictures to touch. New Haven:Yale University Press.

Lipps M., Pelz J. (2004). Yarbus revisited: task-dependent oculomotor behavior. In Journal of Vision, vol. 4.

Massironi M. (1982). Vedere con il disegno. Padova: F. Muzzio.

MorgenthalerW. (a cura di) (198I). Psicodiagnostica Hermann Rorschach. Roma: Edizioni Kappa.

Pasotti S. (1995). Rappresentazione Linguaggi Ermeneutica. Lanciano: Editrice Itinerari.

Pierantoni P. (1999). Forma fluens. Il movimento e la sua rappresentazione nella scienza, nell'arte e nella tecnica. Torino: Bollati Boringhieri.

Trematerra A., lannace G. (2013). The acoustic of the Catacombs of "San Gennaro" in Naples. Proceedings of International Congress on Noise Control Engineering, Innsbruck.

Trematerra A., lannace G. (20 I4). The Acoustic of caves. In Applied Acoustics, 86

Turri E. (2003). Il paesaggio degli uomini: la natura, la cultura, la storia. Bologna: Zanichelli.

Yarbus L. (1967). Eye Movements and Vision. New York: Plenum Press.

\section{Author}

Gerardo Maria Cennamo, Università Telematica Internazionale UNINETTUNO, g.cennamo@uninettunouniversity.net

To cite this chapter. Cennamo Gerardo Maria (202I). Ermeneutica della rappresentazione: la preminenza del disegno nel confronto pluridisciplinare/Representation's hermeneutics: the supremacy of the drawing in the multidisciplinary comparison. In Arena A., Arena M., Mediati D., Raffa P. (a cura di). Connettere. Un disegno per annodare e tessere. Linguaggi Distanze Tecnologie. Atti del $42^{\circ}$ Convegno Internazionale dei Docenti delle Discipline della Rappresentazione/Connecting. Drawing for weaving relationship. Languages Distances Technologies. Proceedings of the $42^{\text {th }}$ International Conference of Representation Disciplines Teachers. Milano: FrancoAngeli Milano: FrancoAngeli, pp. 378-393. 